\title{
Ethnomedicinal Plants Used As Antidote for Snake- Bite and Scorpion-Sting in Bundelkhand (U.P.), India
}

\author{
Vijay Kumar and P.K. Singh \\ Department of Botany Pt. J. N. P. G. College Banda (U. P.), India
}

\begin{abstract}
Snake-bite and Scorpion sting are an important medical emergency in many parts of the the South East Asian Region. It results in the death or chronic disability of many active younger people, specially those involved in agriculture and forestry. During the taxonomic and medicinal survey of Bundelkhand in 2010-2013 the plants were collected and the interview was carried out in local community specially by ethenic groups (Saharia, Kols, Nath, Kabootra, Lodh and Sapera) who are in a good number in the Bundelkhand region of Uttar Pradesh, India. The paper presents 23 Angiospermic species belonging to 21 genera and 16 family.

Key Words : Ethnomedicinal plants, Ethenic groups, Antidote, Bundelkhand.
\end{abstract}

\section{Introduction :}

From ancient times poisonous animal bite is a serious issue in world. Millions of people die every year because of poisonous animal's bite, snake bite cases being the most common culprit. Following this, scorpion sting is also a common and global public health problem associated with substantial sickness and mortality. Conservative sources of snake bite estimate that the number of accidents globally reach 2.5 million and more than 1,25,000 deaths (Wingert and Chan, 1988), annually. In India alone, more than 200,000 cases of snake bite are reported and estimated 35,000 to 50,000 people die (Sharma et al., 2004., John Sudworth, 2006) and number of scorpion stings cases exceeds 1.23 million, of which over 32,250 may be fatal each year(Chippaux, J.P., et al., 2008). Snake bite and scorpion sting are major health hazards that lead to high mortality and great suffering in victims. The monopoly of snake bite healers is because they do not give information to the people, partly due to their unknown materia medica, and occult-mystical nature of their practice. Traditionally people in Bundelkhand specially the local healer (Ojha, Vaid) and other community posses considerable knowledge of the therapeutic properties of local plant species. Local knowledge on ethnomedicine is revolutionary way to recast our conventional knowledge.

\section{Material And Methods :}

The study was conducted in Bundelkhand region (U.P), which comprises seven districts viz. Jhansi, Lalitpur, Jalaun, Hamirpur Mahoba, Banda, and Chitrakoot. The information was collected. Several field trips were made during 2010-2013 specially in the Tribes villages. The indigenous knowledge and therapy of medicinal plants for Snake bite and Scorpion sting care was gathered from the tribe chief, old and experienced informants at different villages and localities. The plants were collected, identified and photographs were taken. Boucher herbarium specimens were deposited in the department of Botany, Pt. J. N. P. G. College Banda (U.P.). OBSERVATION : The present study reveals 23 angiospermic species which are used in treatment of snake-bite and scorpion-sting. The botanical name of each species with family, local name, part used and doses are given below.

1. Acacia catechu Willd.

\begin{tabular}{llll} 
Family & $:$ & \multicolumn{2}{l}{ Mimosaceae } \\
Local Name & & $:$ & Katha / Khair \\
Part used & & $:$ & Bark
\end{tabular}

Doses : Bark is a reputed medicine in the treatment of snake-bite.

2. Acacia sinuate (Lour.) Merr.

Family : Mimosaceae

Local Name : $\quad$ Aita

Part used : Pod

Doses : Pods are used in the treatment of snake-bite.

3. Achyranthes aspera Linn.

$\begin{array}{llll}\text { Family } & : & & \text { Amaranthaceae } \\ \text { Local Name } & & : & \text { Chirchita } \\ \text { Part used } & & : & \text { Root }\end{array}$

Doses : Decoction of root is given in scorpion-sting. 


\begin{tabular}{lll} 
4. Albizia procera (Roxb.) & Benth. \\
Family & : & \multicolumn{2}{l}{ Mimosaceae } \\
Local Name & $:$ & Siris \\
Part used & $:$ & Pods
\end{tabular}

Doses : Pods are considered useful in snake-bite.

5. Alternanthera sessilis (Linn.) DC.

Family : Amaranthaceae

Local Name : $\quad$ Girni

Part used : Root

Doses : Root is used in snake-bite.

6. Amaranthus gracilis Desf.

\begin{tabular}{llll} 
Family & $:$ & & \multicolumn{2}{c}{ Amaranthaceae } \\
Local Name & & $:$ & Chaulai \\
Part used & & $:$ & Leaves
\end{tabular}

Doses : The paste made from leaves is applied to scorpion-sting.

7. Bacopa monnieri (Linn.) Penneli.

Family

: $\quad$ Scrophulariaceae

Local Name $\quad$ : $\quad$ Nir-Bramhi

Part used : $\quad$ Stem \& Leaves

Doses : The decoction of stem and leaves are useful in snake-bite.

8. Barringtonia acutangula (Linn.) Gaertn.

$\begin{array}{llll}\text { Family } & : & \text { Lecythidaceae } \\ \text { Local Name } & & : & \text { Paniha } \\ \text { Part used } & & : & \text { Seed }\end{array}$

Doses : Seeds are used for snake-bites.

9. Capparis zeylanica Linn.

\begin{tabular}{llll} 
Family & $:$ & \multicolumn{2}{l}{ Capparidaceae } \\
Local Name & & $:$ & Bhagnaha \\
Part used & & $:$ & Fruits
\end{tabular}

Doses : The pickled fruits are eaten as a precautionary measure against snake-poisoning.

10. Cleome gynandra Linn.

\begin{tabular}{llll} 
Family & $:$ & \multicolumn{2}{l}{ Cleomaceae } \\
Local Name & & $:$ & Safed hurhur \\
Part used & & $:$ & Whole Plant
\end{tabular}

Doses : Plant sap is applied as an antidote to scorpion-sting.

11. Eclipta alba (Linn.) Hassk.

Family

Asteraceae

Local Name : $\quad$ Ghamra

Part used : $\quad$ Whole plant

Doses : The decoction of plants is considered as an excellent cure for

Scorpion-sting.

12. Euphorbia thymifolia Linn.

$\begin{array}{llll}\text { Family } & : & & \text { Euphorbiaceae } \\ \text { Local Name } & & : & \text { Chutti dudhi } \\ \text { Part used } & & : & \text { Leaves }\end{array}$

Doses : 1-2 gm. Powder of leaf along with black pepper give orally to snakebite patient.

13. Ficus racemosa Linn.

\begin{tabular}{llll} 
Family & $:$ & \multicolumn{2}{l}{ Moraceae } \\
Local Name & & $:$ & Gular \\
Part used & & $:$ & Leaves
\end{tabular}

Doses : The leaf paste used as antidote for scorpion-stings.

14. Holarrhena antidysenterica (Roth.) A. DC. Prodr.

Family : Apocynaceae

Local Name $\quad$ : $\quad$ Indrajau

Part used : $\quad$ Seeds

Doses : The seeds are used as an antidote against poison and relieves pains 
and swellings in snake-bite.

15. Leucas aspera Spreng.

$\begin{array}{llll}\text { Family } & : & & \text { Lamiaceae } \\ \text { Local Name } & & : & \text { Guma } \\ \text { Part used } & & : & \text { Leaves }\end{array}$

Doses : Leaf decoction is given orally in snake- bite.

16. Leucas cephalotes Spreng.

\begin{tabular}{llll} 
Family & $:$ & \multicolumn{2}{l}{ Lamiaceae } \\
Local Name & & $:$ & Kalesher \\
Part used & & $:$ & Fruit
\end{tabular}

Doses : Fruit extract is dropped in ear and given orally at intervals of fifteen minutes as an antidote for snake-bite.

17. Pentapetes phoenicea Linn.

$\begin{array}{llll}\text { Family } & : & \text { Sterculiaceae } \\ \text { Local Name } & & : & \text { Dupahriya } \\ \text { Part used } & & : & \text { Root }\end{array}$

Doses : Root is used in the treatment of snake-bite.

18. Pogostemon benghalense (Burm. f.) O. Kuntze.

$\begin{array}{llll}\text { Family } & : & \text { Lamiaceae } \\ \text { Local Name } & & : & \text { Sangh } \\ \text { Part used } & & : & \text { Root }\end{array}$

Part used

Doses : Root is used in snake-bite.

19. Schleichera oleosa ( Lour.) Oken.

Family : Sapindaceae

Local Name : $\quad$ Kusum

Part used : $\quad$ Flower

Doses : Flower is used for the treatment of snake-bite.

20. Semecarpus anacardium Linn.

$\begin{array}{llll}\text { Family } & : & & \text { Anacardiaceae } \\ \text { Local Name } & & : & \text { Bhella } \\ \text { Part used } & & : & \text { Root }\end{array}$

Doses : Root is useful against snake-bite.

21. Terminalia arjuna (Roxb. ex. DC.) Wt. \& Arn.

\begin{tabular}{llll} 
Family & $:$ & & \multicolumn{2}{c}{ Combretaceae } \\
Local Name & & $:$ & Arjun \\
Part used & & $:$ & Bark
\end{tabular}

Doses : Ash of bark is used in scorpion -sting.

22. Tiliacora acuminate (Lamk.) Miers.

Family : Menispermaceae

Local Name : $\quad$ Karwanath

Part used : Root

Doses : The juice of the root in water is given as a drink to cure snake-bite.

23. Wrightia tinctoria $\mathbf{R}$. Br.

$\begin{array}{llll}\text { Family } & : & \text { Apocynaceae } \\ \text { Local Name } & & : & \text { Dudhi } \\ \text { Part used } & & : & \text { Bark \& Leaves }\end{array}$

Doses : The bark and leaves are useful in snake-bite and scorpion-sting.

RESULT AND DISCUSSION : The ethnic and rural people of Bundelkhand have preserved a large number of traditional knowledge of medicinal uses of plants growing around them. This study shows that knowledge and use of herbal medicine for the treatment of Snake bite and Scorpion sting ailments which is common problems of Bundelkhand, particularly in rainy season. 16 Species are used in snake-bite 6 species are used in scorpionsting and 1 species is used in both problems.

\section{Acknowledgments :}

The authors are very grateful to the ethenic groups (Saharia, Kols, Nath, Kabootra, Lodh and Sapera) of Bundelkhand. for sharing their knowledge and Dr. N. L. Shukla Principal Pt. J. N. P. G. College Banda for providing necessary facilities. 


\section{References:}

[1]. Ambast, S.P. (1986) The useful plants of India. Publication and information director, CSIR, New Delhi, India 1-918.

[2]. Ayyanar, M. and Ignacimuthu, S. (2005) Medicinal plants used by the tribal of Tirunelveli hills, Tamil Nadu to treat poisonous bites and skin diseases. Indian Journal of Traditional Knowledge 4: 229-236.

[3]. Bahekar, Satish. Kale, Ranjana. And Nagpure, Shailesh (2012). A Review on medicinal plants used in scorpion bite treatment in India. Mintage J.of Pharmaceutical \& Medical Sciences. 1-6.

[4]. Chippaux, J.P., Goyffon, M. Epidemiology of scorpionism: a global appraisal. Acta Trop. 107, 2008, 71-79.

[5]. Kumar, Vijay. Sachan, P. Nigam, G. and Singh P. K. 2010. Some ethnomedicinal plants of Chitrakoot district (U.P.). J. Biozone,V. 2 (1\&2). 270-283.

[6]. Kumar, Vijay and Singh, P. K. 2011. Ethnobotanical studies in Saharia tribes of Lalitpur district (U.P.). J. Progressive research 7 (1), P. 92-95.

[7]. Prajapati, N.D. Purohit, S.S. Sharma, A.K. and Kumar Tarun; 2004. A Handbook of Medicinal plant, Agrobios (India).

[8]. Sharma SK, Chappiux F, Nalhamb A, Patrick A, Louis L, Shekhar K. Impact of snakebites and determinants of fatal outcomes in southeastern Nepal. Am J Trop Med Hyg. 2004;71(2):234-238.

[9]. Wingert, W., Chan, L., 1988. Rattlesnake bites in southern California and rationale for recommended treatment. West J Med 148, 3744.

[10]. John Sudworth, 2006. India 's battle against snake bites. BBC news. 